\title{
Implementation of Multicultural Education Values In History Learning at SMA Negeri Siwalima Ambon
}

\author{
Rianko Luturmas \\ Unversitas Sebelas Maret \\ riankoluturmas@gmail.com
}

\section{Article History}

accepted 1/09/2020

approved 4/10/2020

published 1/12/2020

\begin{abstract}
Multicultural education is an educational concept that recognizes differences / diversity in a frame of togetherness and equality. The concept of multicultural education is relevant in the concept of a country that has cultural diversity like Indonesia. Education is one of the effective media to develop multiculturalist awareness. Educational curriculum development must be based on the socio-cultural context of the community. So it must be realized that historical learning has a big role in the development of multicultural education, considering that historical pursuits present various historical facts of the nation which of course have a diversity of identities and cultures. Through identification of historical material contained in the syllabus of history subjects in schools, it is found that some content is loaded with the development of multicultural values.
\end{abstract}

Keywords: Multicultural education, history learning

\begin{abstract}
Abstrak
Pendidikan multikultural merupakan konsep pendidikan yang mengakui perbedaan/keberagaman dalam suatu bingkai kebersamaan dan kesederajatan. Konsep pendidikan multikultural relevan dalam konsep negara yang mempunyai keanekaragaman budaya seperti Indonesia. Pendidikan merupakan salah satu media efektif untuk mengembangkan kesadaran multikulturalis. Pengembangan kurikulum pendidikan haruslah berlandaskan konteks sosial kebudayaan masyarakat. Maka harus disadari bahwa Pembelajaran sejarah memiliki andil besar dalam pengembangan pendidikan multikultural, mengingat pembejaran sejarah menyajikan berbagai fakta sejarah bangsa yang tentunya memiliki keberagaman identitas dan budaya. Melalui identifikasi pada materi sejarah yang terdapat pada silabus mata pelajaran sejarah di sekolah ditemukan beberapa konten yang sarat dengan pengembangan nilai multikultural.

Kata Kunci: Pendidikan multikultural, pembelajaran sejarah
\end{abstract}

Social, Humanities, and Education Studies (SHEs): Conference Series p-ISSN 2620-9284 https://jurnal.uns.ac.id/shes e-ISSN 2620-9292 
SHEs: Conference Series 3 (2) (2020) 69 - 76

\section{PENDAHULUAN}

Indonesia merupakan negara yang sedang tumbuh "menuju demokrasi", di mana demokrasi pada awalnya adalah aspirasi politik yang ditempuh melalui suatu prosoes yang berpusat pada rakyat, artinya aspirasi rakyat merupakan suatu inspirasi dan sekaligus merupakan penentu arah proses pengambilan keputusan publik. Sehingga masyarakat dan semua lapisan, etnis, agama dan sebagainya merasa harus ikut dilibatkan dan diakomodir pendapat dan kepentingannya.

Indonesia adalah salah satu negara multikultural terbesar di dunia. Kebenaran dari pernyataan ini dapat dilihat dari kondisi sosio-kultur maupun geografis yang begitu beragam dan luas. Indonesia memiliki 13.000 pulau yang membentang dari Sabang sampai Merauke dengan terdiri dari ragam macam suku, tradisi kepercayaan, bahasa, agama, budaya, adat istiadat. Kymlimcka (dalam Handoyo, 2015, hlm.14) memperkirakan, ada 184 negara merdeka di dunia terdiri atas 600 kelompok bahasa hidup dan 5000 kelompok etnik. Ditambah data terakhir menunjukan bahwa jumlah etnik di dunia, seperlimanya terdapat di Indonesia yang memiliki lebih dari 1000 etnis atau subetnis, Suryadinata (2003, hlm.6). Kemajemukan ini merupakan kekayaan yang jarang dimiliki oleh bangsabangsa lainya. Banyaknya kelompok etnis tersebut acap kali menjadi kekhawatiran dapat menimbulkan sejumlah persoalan dan secara potesial mudah pecah akibat adanya perbedaan bahasa, politik, ekonomi. Perlu adanya upaya pendewasaan kepada mayarakat tentang bagaimana negara ini berdiri dan tetap menjaga toleransi serta kebhinekaan sebagai bangsa yang multikultur dan menggunakan strategi pemajuan kebudayaan. Artinya, multikulturlisme tujuan dalam langkah mengambil sebuah kebijakan untuk menjunjung tinggi sebuah nilai perbedaan, kesederajatan, hak asasi manusia, sebagai instrumen pengambilan kebijakan bagi wilayah yang memiliki keberagaman untuk menghindari perpecahan pada struktur sosial.

Pada kontekstualitas multikulturlisme ini dapat diukur pada dua hubungan yakni vertikal dan horizontal. Aspek vertikal berhubungan dengan kelas sosial yang menjelaskan kedudukan manusia sesuai dengan klasifikasi sosialnya. Seperti dari ekonominya apakah dia masuk pada golongan atas, menengah atau bawah. Sedangkan aspek horizontal hubungan yang menjelaskan kedudukan manusia berdasarkan ras, etnik, adat istiadat. Perbedaan secara horizontal dimaknai sebagai perbedaan yang diukur berdasarkan kualitas dari unsur-unsur yang membuat keragaman tersebut, Mutakin (dalam Handoyo, 2015, hlm.7). Terjadinya pertemuan manusia yang kompleks dan beragam secara kultur serta merefleksikan pentingnya menghargai perbedaan budaya, ras, seksualitas, gender, agama, status sosial ekonomi sudah terjadi saat adanya ekspansi perdagangan dari negara asing ke nusantara. Melalui jalur perdagangan terjadi pertukaran budaya, kebiasaan serta interaksi sosial. Proses pertukaran budaya melalui kegiatan ekonomi, politik hingga adanya perkawinan antara kaum pendatang dan pribumi kemudian menghasilkan perpaduan yang melahirkan budaya baru dalam kebiasaan hidup. Merujuk dari penjelasan di atas bahwa konseptualisasi multikulturalisme dapat diterapkan kepada pendidikan yang berarti adanya proses transformasi pengetahuan yang ditimbulkan dari interaksi peserta didik yang memiliki latar belakang berbeda, suku, ras, budaya serta kebiasaan yang mencerminkan watak serta karakter yang berbeda. Melalui proses pendidikan itulah, akan terciptanya pengalaman, pengetahuan dengan harapan peserta didik mampu mengaktualisasikan diri melalui cara mereka hidup berdampingan saling menghargai satu sama lainya.

Dalam pengembangan kurikulum pendidikan di Indonesia kebudayaan menjadi salah satu landasan kuat, mengingat kurikulum harus dapat mengakomodasi semua kebutuhan peserta didik yang berasal dari berbagai kebudayaan yang ada, oleh sebab itu menempatkan unsur kebudayaan sebagai indikator utama dalam pengembangan 
kurikulum adalah keniscahayaan. Pasca reformasi pendidikan multikultural (multi budaya) semakin mendapat tempat untuk dikembangkan dalam kurikulum pendidikan di Indonesia. Pengembangan terebut menjadi sarana alternatif dalam pemecahan konflik yang selama masa orde baru marak terjadi, pendekatan pendidikan multikultural juga dapat membendung arus globalisasi yang membuat peserta didik tercerabut dari akar budayanya (Zuhdi, 2014: 308; Mahfud, 2016: 125). Salah satu bentuk kurikulum tertulis adalah silabus yang di dalamnya memuat garis besar, ringkasan, abstrak, atau poin utama dari isi atau materi pembelajaran (Salim, 1987: 98). Guru sebagai pengembang kurikulum harus memiliki keterampilan dalam memahami apa sebenarnya tujuan-tujuan yang diharapkan dari sebuah naskah kurikulum yang berbentuk teks tersebut. Oleh sebab itu, penting kiranya untuk menganalisis muatan dari sebuah silabus untuk kemudian diidentifikasi tujuan-tujuan yang ingin dicapai. Pendidikan sejarah merupakan mata pelajaran yang tujuannya memiliki kaitan dengan pembentukan watak bangsa. Pendidikan sejarah memiliki peran strategis dalam membentuk warga negara yang memahami nilai-nilai luhur bangsa, yang dalam hal ini juga termasuk nilai penghargaan terhadap keberagaman kebudayaan yang telah menjadi jati diri bangsa Indonesia. Oleh sebab itu, penting kiranya diidentifikasi dan dianalisis nilainilai multikultural yang terdapat pada perangkat kurikulum tersebut, hal ini akan menjadi arah dan pedoman bagi guru dalam melaksanakan proses pembelajaran di sekolah.

Selain itu juga kelas yang bersifat multikulrural ini merupakan kelas dinamis yang terdiri dari berbagai macam latar belakang siswanya, dalam memberikan pembelajaran sejarah Indonesia sangat variatif. Seperti dengan memprovokasi menjadi agen perubahan, menjadi relawan keberagaman, serta agen perekat persatuan dan persatuan Indonesia. Motiviasi ini diberikan setelah pembelajaran sejarah proklamasi kemerdekaan diberikan. Sehingga mampu membuat siswanya untuk bergerak bukan hanya sebagai penerima hasil kemerdekaan akan tetapi terlibat untuk melanjutkan misi kemerdekaan yaitu menerima keberagamanan. Peneliti menemukan pembelajaran sejarah Indonesia di SMA Negeri Siwalima Ambon ini guru dan siswa tidak cukup banyak menggali teori dalam buku didalam kelas, melainkan menyampaikan materi yang berkaitan dengan nilai pendidikan multikulturalisme dalam pembelajaran sejarah. Guru mendorong siswanya untuk terlibat dan berperan aktif dalam mencari sumber di luar kelas dan kemudian didiskusikan bersama apa yang ditemukan oleh siswanya.

\section{METODE}

Model pendekatan dalam penelitian ini bersifat deskriptif kualitatif dengan pendekatan naturalistik. Pendekatan naturalistik digunakan untuk menggambarkan secara alami, lengkap, mendalam, dan utuh mengenai multikulturalisme dan pendidikan nilai dalam pembelajaran sejarah di SMA Negeri Siwalima Ambon. Penelitian dilakukan untuk menemukan dan menggambarkan tentang pendidikan nilai-nilai multikulturalisme dalam pembelajaran sejarah di SMA Negeri Siwalima Ambon sebagai upaya pencegahan budaya kekerasan dikalangan pelajar. Oleh karena itu, penelitian bersifat eksplorasi, yang menjelaskan suatu fenomena yang detail, menyeluruh dan mendalam. (Noeng Muhadjir, 2011: 192, 194). Tempat dan Waktu Penelitian Penelitian dilakukan di SMA Negeri Siwalima Ambon. Berdasarkan teknikpurposive sampling yaitu teknik penentuan sampel dengan pertimbangan tertentu yang telah di tentukan oleh peneliti, maka sampel penelitian ditentukan di SMA Negeri Siwalima Ambon. Pertimbangan landasan pemilihan lokasi yaitu SMA Negeri Siwalima Ambon sampel dari sekolah negeri yang bersifat majemuk. Berdasarkan pertimbangan tersebut, hasil penelitian dapat menggambarkan suatu kesimpulan yang menyeluruh tentang multikulturalisme dan pendidikan nilai dalam pembelajaran sejarah di SMA Negeri Siwalima Ambon. 


\section{Multikulturalisme}

\section{HASIL DAN PEMBAHASAN}

Pemahaman terhadap kata multikulturalisme adalah kebudayaan. Secara etimologis multikulturalisme dibentuk dari kata multi (banyak), kultur (budaya), dan isme (aliran/paham). Secara hakiki dalam kata itu terkandung pengakuan akan martabat manusia yang hidup dalam komunitasnya dengan kebudayaannya masing-masing yang unik. Konsep multikulturalisme tidaklah dapat disamakan dengan konsep keanekaragaman secara suku bangsa atau kebudayaan saja yang menjadi ciri masyarakat majemuk, karena multikulturalisme menekankan keanekaragaman kebudayaan dalam kesederajatan atau kesetaraan budaya (Mahfud, 2016: 75), atau menurut Kymlicka (2015: 2) adalah gerakan politik tentang hak-hak minoritas yang selama ini diberlakukan tidak adil oleh sistem liberalisme. Kymlicka menerangkan bahwa sistem liberal yang mengedepankan hak asasi manusia belum cukup dalam menyelesaikan masalah mengenai keberadaan kelompok minoritas, karena selama ini minoritas dipaksakan untuk berasimilasi, menerima bahasa, agama, dan adat dari kelompok mayoritas, bahkan cara radikal juga telah dilakukan dengan pembersihan etnis (genosida) seperti yang terjadi di Amerika dan Jerman. Dari penjelasan di atas dapat dikatakan bahwa multikuturalisme merupakan sebuah gerakan untuk mewujudkan kesederajatan dalam perbedaan budaya.

Secara teoritis pengertian pandangan multikulturlisme sebagai dunia yang kemudian diwujudkan dalam politic of recognition di paparkan oleh Bikhu Parekh (Mahfud, 2016: 93-95) dalam bukunya National Culture and Multiculturalisme (1997), yang secara jelas membedakan lima macam multikulturalisme sebagai berikut:

1) Multikulturalisme isolasionis dimana berbagai kelompok menjalankan hidup secara otonom yang hanya terlibat interaksi satu sama lain.

2) Multikulturalisme akomodatif dimana kelompok dominan membuat penyesuaian dengan kaum minoritas.

3) Multikulturalisme otonomis dimana kelompok-kelompok kultural utama berusaha mewujudkankesetaraan dengan budaya dominan dan mengangankan kehidupan otonom dalam kerangka politik yang secara kolektif dapat diterima.

4) Multikulturalisme kritikal dan interaktif dimana setiap kelompok menuntut kultur kolektif.

5) Multikulturalisme cosmopolitan dimana paham yang berusaha menghapus batas-batas kultural sehingga setiap individu tidak terikat pada budaya tertentu.

Dalam konteks Indonesia, menurut Soyomukti (2015: 101) bahwa paham multikulturalisme di Indonesia menjadi semarak kembali setelah masyarakat

belajar dari pengalaman pahit dariditerapkannya politik monokulturalisme selama

32 tahun oleh kekuasaan Orde Baru. Salah satu contoh konkret dari praktek monokulturalisme adalah diskriminasi terhadap orang Tionghoa yang berkaitan

dengan penyelenggaraan perayaan agama. Pada Januari 2000, presiden

Abdurrahman Wahid mencabut instruksi presiden nomor 41 tahun 1967 yang kemudian mengakhiri diskriminasi tersebut (Bertrand, 2012: 166)

2. Pendidikan Multikultural Dalam Pembelajaran Sejarah

Pendidikan multikultural berkomitmen pada tujuan memberikan seluruh peserta didik tanpa memandang status sosial ekonomi; jender; orientasi seksual; atau latar belakang etnis, rasa tau budaya- kesempatan yang setara untuk belajar di sekolah (Parkay \& Standford, 2011: 35). Pendidikan multikultural lebih mengarahkan peserta didik untuk bersikap dan berpandangan toleran (inklusif) terhadap realitas sosial masyarakat yang beragam, baik dalam hal budaya, suku, 
ras, etnis maupun agama. Paradigma ini dimaksudkan bahwa kita hendaknya apresiatif terhadap budaya orang lain, perbedaan dan keberagaman merupakan kekayaan (Mahfud, 2016: 185-187).

Keragaman bangsa bukan saja dalam hal penduduknya dengan berbagai latar belakang keagamaan, suku, orientasi budaya, tetapi juga dalam arti geografis karena Indonesia merupakan negara kepulauan paling besar di dunia (Sindhunata, 2000: 105). Dalam konteks Indonesia yang multikultural dewasa ini, menurut Sultan Hamengkubuwono (2008: 14) yang harus dan tetap dijadikan basis integrasi nasional adalah Bhinneka Tunggal Ika. la mangatakan pengalaman telah mengajarkan bahwa bukan semangat kemanunggalan (tunggal-ika) yang potensial bisa melahirkan kesatuan dan persatuan, melainkan pengakuan akan pluralitas (kebhinekaan), selain itu kesediaan untuk menghormati kemajemukan tersebut. Oleh sebab itu, kehadiran pendidikan yang berlandaskan semangat multikultural adalah suatu keniscahayaan bagi tercapainya kerukunan dalam praktek berbangsa, terkhusus Indonesia.

Pendidikan diberi tanggung jawab untuk menciptakan rasa kemanusiaan, moral, dan kepribadian yang mendukung terjadinya kedamaian di masyarakat melalui penyebaran pengetahuan, wawasan, dan spirit bagi generasi (anakanak, remaja, pemuda secara khusus, dan rakyat secara umum). Peran pendidikan sangat penting untuk menciptakan masyarakat yang cerdas, damai, terbuka, dan demokratis (Nurhadi, 2004: 2-3). Artinya, pendidikan multikulturlisme tujuan dalam langkah mengambil sebuah kebijakan untuk menjunjung tinggi sebuah nilai perbedaan, kesederajatan, hak asasi manusia, sebagai instrumen pengambilan kebijakan bagi wilayah yang memiliki keberagaman untuk menghindari perpecahan pada struktur sosial. Perkembangan peradaban manusia di Indonesia melalui proses perkembangan pengetahuan, sehingga menghasilkan sebuah konsensus bersama di tengah pada waktu itu bangsa kita hidup diberbagai kepulauan. Adapun bangsa sebagai konsep sebenarnya belum terlalu lama, secara formal dinyatakan dalam Sumpah Pemuda 28 Oktober 1928. Terjadinya peristiwa tersebut dapat diartikan merupakan sebagai tonggak sejarah lahirnya bangsa. Indonesia berdiri atas dasar kesamaan dari berbagai masyarakat dan keinginan untuk hidup bersama dalam negara bernama Republik Indonesia. Pemahaman terhadap Negara Republik Indonesia (NKRI) nampak masih terbelenggu dengan orientasi kedaerahan, kepulauan. Dengan pembelajaran sejarah diharapkan dapat mengantarkan peserta didik menjadi warga negara yang berpikir kritis dan demokratis, menjunjung tinggi kemerdekaan dan mencintai tanah air, toleransi dan menghargai orang lain serta memiliki kearifan dan kecerdasan sosial. Sebagai bangsa yang sangat menjungjung tinggi nilai martabat kebangsaan yang telah diwarisi oleh para pendiri bangsa (founding father).

Pendidikan multikulturalisme dapat diarahkan untuk membangun karakter peserta didik dengan latar belakang budaya yang pluralis. Sehingga mereka akan menjungjung tinggi perbedaan, kemerdekaan, toleransi sehingga melahirkan generasi yang memiliki motivasi tinggi dalam menghadapi perkembangan zaman, pendidikan ini jangan hanya sebatas wacana. Sebagai wacana baru terminologi pendidikan multikultur sesungguhnya belum begitu jelas dan masih terdapat perdebatan diantara para pakar (Sudrajat, 2014, hlm.86). Menanamkan serta memberikan pemhaman kesadaran multikultur dapat diterima oleh peserta didik setelah adanya proses pengakuan individu terhadap lingkungan sosialnya.

Pendidikan sejarah memiliki peran dalam menginternalisasi nilai-nilai luhur bangsa kepada peserta didik. Dalam buku Prasangka dan Konflik, Liliweri mengemukakan bahwa sumber konflik yang mendorong situasi disentigrasi ada yang berasal dari faktor historis. Oleh sebab itu, dalam mengajar sejarah, guru harus mampu menyajikan interpretasi sejarah yang memiliki kebermaknaan bagi peserta 
didik (Zuhdi, 2014: 311). Hal demikian dimaksud karena pemahaman terhadap makna dalam setiap fakta sejarah adalah sesuatu yang prinsipil. Pelajaran sejarah merupakan pelajaran yang tujuannya memiliki kaitan dengan pembentukan watak bangsa (Mulyana, 2009: 79), proses internalisasi nilai-nilai peristiwa masa lalu berupa asal usul, silsilah, pengalaman kolektif dan keteladan pelaku sejarah dengan output yang meliputi pemahaman perisitiwa sejarah bangsa, meneladani kearifan, dan sikap bijak pelaku sejarah (Garvey, 2015).

Dari penjelasan di atas maka pendekatan multikultural dalam kurikulum sejarah harus dapat mengakomodasi perbedaan kultural peserta didik, memanfaatkan kebudayaan mereka sebagai sumber konten dan sebagai titik berangkat untuk pengembangan kebudayaan, pemahaman terhadap kebudayaan orang lain, toleransi, membangkitkan semangat kebangsaan berdasarkan Bhineka Tunggal Ika, mengembangkan prilaku yang etis, dan dapat memanfaatkan kebudayaan pribadi peserta didik sebagai bagian dari entybehavior peserta didik sehingga dapat menciptakan "kesempatan yang sama bagi peserta didik untuk berprestasi" (Hasan, 2012: 109).

Hasan (2012: 110) menegaskan bahwa kurikulum pendidikan sejarah tidak boleh menggunakan wawasan bahwa suatu kesatuan bangsa haruslah didasarkan pada satu kesamaan yang ada, dan kurikulum mencoba mengubah perbedaan menjadi kesamaan. Dengan demikian, alternatif untuk menempatkan pembelajaran sejarah berbasis multikultural yakni melalui sejarah lokal. Melalui sejarah lokal pendidikan sejarah akan menyajikan keberagaman budaya yang mesti diketahui peserta didik dan kemudian dipertahankan sebagai suatu kekayaan bangsa. Pendidikan sejarah tidak lagi terpusat pada sejarah nasional, melainkan harus dikembangkan dengan mempelajari sejarah lokal, dengan demikian peserta didik mempelajari identitasnya dan mengetahui jatidirinya sebagai warga bangsa (Zuhdi, 2017: 39). Pengungkapan berbagai sisi kehidupan atau sejarah dalam lokalitas, akan semakin menggugah kesadaran betapa masing-masing budaya memiliki keanekaragaman nilai-nilai yang luhur (Supardi, 2014: 96).

Zuhdi (2017: 138) memberi contoh konten sejarah yang memiliki kaitan dengan semangat multikulturalisme, salah satunya adalah sejarah maritim Indonesia. Nenek moyang bangsa Indonesia telah memiliki rasa toleransi yang tinggi, hal ini dibuktikan dengan hubungan baik dalam perdagangan antar pulau di Nusantara. Oleh sebab itu, pengertian yang benar untuk negara kepulauan Indonesia "bukan pulau-pulau yang dikelilingi laut", melainkan "laut yang ditaburi pulau-pulau". Untuk mewujudkan pendidikan multikultural dalam pembelajaran sejarah, Hasan (2012) menegaskan beberapa hal pokok yang harus diimplementasikan dalam kurikulum pendidikan sejarah, antara lain:

1) Tujuan pendidikan sejarah untuk masa kini dan masa akan datang harus memperhitungkan adanya keragaman budaya bangsa. Tujuan pendidikan sejarah tidak boleh lagi hanya mengembangkan pemahaman sejarah yang berdasarkan satu penafsiran yang didominasi oleh satu budaya dan mengorbankan budaya lain.

2) Kurikulum pendidikan sejarah masa depan harus mengakomodasi berbagai peristiwa sejarah yang terjadi di suatu lokal yang paling kecil sekali pun.

3) Ketersediaan sumber atau cerita sejarah.

4) Komponen asesmen mengenai ketercapaian tujuan pembelajaran.

Berdasarkan hal di atas, maka salah satu alternatif pelaksanaan pendidikan sejarah adalah melalui pendekatan kontekstual yang mengaitkan antara teks dengan konteks (Komalasari, 2014: 7, Johnson, 2007: 65). Melalui pendekatan kontekstual proses pembelajaran akan lebih bermakna karena peserta didik langsung dihadapkan dengan hal-hal yang berada disekelilingnya. Pendekatan ini 
sangat mendukung pembelajaran sejarah berbasis multikultural karena apa yang kemudian diketahui oleh peserta didik kemudian dapat dibandingkannya dengan hal-hal lain yang berbeda dan terdapat di luar lingkungan dan budaya peserta didik.

\section{SIMPULAN}

Multikulturalisme pada dasarnya adalah gerakan kesetaraan dan kesederajatan dalam keberagaman. Titik penting dari multikulturalisme adalah adanya upaya saling keterbukaan dan saling menerima perbedaan. Yang harus dilakukan oleh guru sejarah di dalam kelas yaitu harus memiliki: 1) pemahaman konseptual yang memadai berupa pengetahuan dalam konteks isuisu global; 2) guru harus memiliki pengalaman lintas budaya berupa pemahaman dan interaksi atas perbedaan latar belakang masingmasing orang; dan 3) guru harus menguasai keterampilan pedagogis yang berkaitan dengan metode, pendekatan, strategi, dan model. Dalam pembelajaran sejarah Indonesia di SMA Negeri Siwalima Ambon sudah mencapai keharmonisan, keragaman, motivasi belajar untuk melakukan sebuah tindakan yang berkaitan dengan kepentingan nasional. Terbukti dalam kegiatan pendahuluan sebelum pembelajaran peserta didik duduk berdampingan dengan yang berbeda agama. Selama dalam pembelajran, peserta didik mampu melaksanakan arahan guru sesuai dengan metode pembelejaran yang diterapkan seperti observasi, menanya, merumsukan masalah, mengasosiasi dan mengkomunikasikan. Meskipun dalam perangkat Rencana Pelaksanaan Pembelajaran (RPP) serta dalam dokumen pembelajaran tidak dicantumkan konsep-konsep nilai multikultural secara spesifik sebagai pedoman proses pembelajaran sejarah Indonesia. Padahal pengembangan model pembelajaran berbasis nilai multikultural dapat dilakukan melalui rencana pembelajaran, penyajian bahan ajar, mengembangkan metode pendekatan pembelajaran serta menggunakan penilaian yang mampu mendorong siswa untuk menginternalisasikan nilai-nilai multikultural ke dalam dirinya.

\section{DAFTAR PUSTAKA}

Bertrend, Jasques. 2012. Nasionalisme dan Konflik Etnis di Indonesia. Terjemahan. Yogyakarta: Ombak.

Buwono, Sultan Hamengku. 2008. Merajut Kembali Ke-Indonesiaan Kita. Jakarta: Gramedia Pustaka Utama.

Garvey, Brian \& Mary Krug. 2015. Model-model Pembelajaran Sejarah di Sekolah Menangah. Terjemahan. Yogyakarta: Ombak.

Hasan, S. Hamid. 2012. Pendidikan Sejarah Indonesia: Isu dalam Ide dan Pembelajaran. Bandung: Rizqi Press.

Johnson, Elaine B. 2007. Contextual Teaching and Learning. Terjemahan. Bandung: MLC.

Komalasari, Kokom. 2011. Pembelajaran Kontekstual: Konsep dan Aplikasi. Bandung: Rafika Aditama.

Kymlicka, W. 2015. Kewargaan Multikultural. Terjemahan. Jakarta: LP3ES Mahfud, Choirul. 2016. Pendidikan Mutikultural. Yogyakarta: Pustaka Pelajar 
Mulyana, Agus \& Darmiasti. 2009. Historiografi di Indonesia: dari Magis-Religius hingga Strukturis. Bandung: Refika Aditama.

Noeng, Muhadjir. 2011. Metodologi Penelitian.Yogyakarta: Rake Sarasin.

Nurhadi. 2004. Kurikulum 2004: Pertanyaan dan Jawaban. Jakarta: PT. Gramedia Parkay, Forrest. W \& Standford. 2011. Menjadi Seorang Guru. Terjemahan. Jakarta: Indeks.

Sidhunata (Ed.). 2000. Menggegas Paradigma Baru Pendidikan: Demokrasi, Otonomi, Civil Society, Globalisasi. Yogyakarta: Kanisius.

Soyomukti, Nurani. 2015. Teori-teori Pendidikan: dari Tradisional, (neo) Liberal, MarxisSosialis, hingga Postmodern. Yogyakarta: Ar-Ruzz Media.

Supardi. 2014. Pendidikan Multikultural dalam Pembelajaran Sejarah Lokal. Jurnal Pembangunan Pendidikan: Fondasi dan Aplikasi, 2 (1), hlm 91-99.

Zuhdi, Susanto. 2014. Nasionalisme, Laut, dan Sejarah. Depok: Komunitas Bambu.

Zuhdi, Susanto. 2017. Integrasi Bangsa dalam Bingkai Keindonesiaan. Jakarta: Wedatama Widya Sastra. 